\title{
Eco-socio Impact of Mineral Resource Mining in the Karamoja Region of Uganda
}

\author{
Estellina Namutebi ${ }^{1}$
}

(C) Uganda Martyrs University

\begin{abstract}
Mining is one of the prolific activities geared towards poverty eradication, but an elusive goal for most government leaders in developing countries. Oftentimes, the economic aspect of mining overshadows ecological and social needs in context of host communities. For that reason, Karamoja region has experienced violent ethnic conflicts, which has made it difficult to trust mining activities to transform the area and contribute to healing of the deep-seated animosity within ethnic groups. This study used interviews and focus group discussions among artisanal miners and the data obtained was content analysed. The outcomes indicated that mineral resource mining activities are still in their infancy, yet environmental degradation is visible and human rights violations and escalating disagreements between communities are also evident. Therefore, peaceful co-existence is a prerequisite between mining companies and the Karamajong to achieve sustainable eco-socio development in Karamoja region. Moreover, the local people's participation in mining activities is instrumental in achieving sustainable development.
\end{abstract}

Key words $\cdot$ Eco-socio $\cdot$ Mineral resource $\cdot$ Mining $\cdot$ Karamajong

Impact éco-social de l'exploitation des ressources minières dans la région de Karamoja en Ouganda

Résumé. L'exploitation minière est l'une des activités prolifiques visant à éliminer la pauvreté, mais un objectif lointain pour la plupart de leaders du gouvernement dans des pays en voie de développement. Souvent, l'aspect économique de l'exploitation minière éclipse les besoins écologiques et sociaux dans le contexte des communautés resident dans l'espace regorgeant ces ressources minérales. Pour cette raison, la région de Karamoja a connu des conflits éthniques violents, ce qui a rendu difficile de faire confiance à l'activité minière pour transformer la région et ainsi contribuer à la guérison de l'animosité profonde au sein de groupes éthniques. Cette étude a fait usage d'interviews et des discussions en groupe parmi les miniers artisanaux et les données obtenues ont été analysées d'après le contenu. Les résultats indiquent que les activités d'extraction des ressources minières dans la region de Karamoja sont encore au stade debutant alors que la dégradation écologique y est déjà visible et les violations des droits bumains sont manifestes y compris aussi l'escalade des conflits entre les communautés. Par conséquent, la co-existence pacifique est un préalable entre les compagnies minières et les Karamajong, afin de réaliser le développement éco-social durable dans la région de Karamoja. En outre, la participation de la population locale dans les activités d'exploitation minière joue un rôle déterminant dans la réalisation du développement durable.

Mots clés: Eco-social $\bullet$ Ressources minieres $\bullet$ l'extraction minière $\bullet$ Karamajong

\section{Introduction}

In a world of several anthropogenic controversies, every human act counts. Each act is measured by its ability to transform the human community and conserve the

\footnotetext{
${ }^{1}$ Uganda Martyrs University, Email: enamutebi@umu.ac.ug
} 
ecosystem. However, driven by their selfish interests, humans tend to exploit the available resources without thinking about the future of the local community (Farber, et al. 2002). Thus, Worrall et al. (2009) believe that mines have negatively impacted society and the environment, which has left a legacy in the minds of people to judge the future performers in the mine business. In Uganda, private companies and individuals have flocked Karamoja to grab the enormous virgin land of warriors in search of gold and other minerals. Besides, this wave has left many Karamajong without land for tilling or grazing. Yet, based on historical accounts, the nomadic pastoral communities of Karamoja region have gone through a decade of intra-ethnic violent conflicts and it is now difficult to determine whether mining activities would transform the region (Nangiro and Davies, 2013).

The government of Uganda has a national legal policy attached to mineral resource mining. Particularly, Karamoja region mineral management policy falls under various statutory legal regulations. For instance, the Mine Act (2003) and Mining Regulation (2004) provide that those involved in mining should consult with other "legislative bodies such as National Environmental Regulation (NER, 2001) and Water Resource Regulation (1998) including the NER of (2000)" (Hinton et al., 2011:29). However, this design does not include all stakeholders especially the local/host communities. Moreover, the contractors and those contracted have not followed the proper channels of mineral resource exploration; instead, they have concentrated on its beneficial aspect, hence forgetting the precarious effect of mining on the environment and the local community. Thus, gold and marble quarrying are already not eco-friendly activities because they have led to water pollution, which affects the health of both biodiversity and humans. The purpose of the study was to assess the eco-socio impact of mining in Karamoja region, with specific focus on three Districts (Moroto, Amudat and Nakapiripiriti) where mineral resource explorations and mining are taking place. In this regard, this paper aims at answering the following questions:

1. How can mining activities in Karamoja transform the region and improve the current eco-socio challenges?

2. What is the reaction of the Karamajong towards government involvement in mineral resource mining in the region?

3. What is the attitude of the Private Companies towards Karamajong community values?

Furthermore, the paper highlights the fact that economic aspects of mining usually overshadow ecological and social needs of the host communities. In this current era of mineral resource exploration in developing countries, particularly in areas occupied by indigenous people, the eco-socio impact of mining needs to be studied and addressed. Mining often results into long-term negative ecological and socio impacts, its ability to economically transform an area notwithstanding. This perspective should be kept in mind while exploring and mining mineral resources in Karamoja region. 
Therefore, interviews and focus group discussions were used to collect data in three districts: Amudat, Moroto and Nakapiripiriti, where mineral resource exploration and mining activities are widespread. Various groups of artisanal miners and local government officers from the three districts were interviewed. In addition, secondary data was obtained through analysis of documents on mineral resource exploration and mining in the region that belonged to the Government of Uganda, private individuals and companies/institutions and the local community. This was aimed at obtaining government's opinion on mining concession in Karamoja. These documents gave insights into the past and current situation and a glimpse into the future of mining activities in the region. However, there was limited access to some of the documents that were supposed to be examined; for instance, local government minutes on mining in the region and internal documents on contracts for private companies. What could be accessed were only frameworks on contracts.

\section{Contextual structure of Karamoja region}

The region under study lies in the far north-eastern part of Uganda. It is comprised of seven districts, namely Abim, Amudat, Kaabong, Kotido, Moroto, Nakapiripirit and Napak, which are located in both dry-tropic and semi-desert climate. The word 'Karamoja' originates from the word 'ekar ngimojong', which is derived from ije language of the Karamajong, one of the Nilotic languages in the sub-Saharan Africa. It means 'the old man can walk or sit' (Ager, 1998). It is by bordered by Kenya in the east and South Sudan in the north. Karamoja shares similar cultural values with the Masai and Dinkas of South Sudan. The region is home to 1.1 million people and $82 \%$ of these live in utter poverty (Adoch and Semakula, 2011:2; World Bank 2006; OCHA/OPM, 2008; OPM, 2010). The environment in Karamoja region is harsh, mostly arid; agricultural production is reliant on rainfall, yet drought conditions generally lead to failed harvests (Powell, 2010). With the recent disarmament, the remnant pastoralists among the Karamajong supplement pastoralism with subsistence farming. However, the semi-arid weather has pushed many Karamajong to artisanal mining in order to earn a living for their families. Besides, artisanal mining has always been a perilous source of income for the Karamojong (Hinton, 2011). It is obvious that mineral resources have been producing more than "90\% of metallic equipment, which supports approximately 200,000 households in Karamoja" (Hinton et al., 2011:3). These metallic products, particularly gold, are mineral extracts from open pits, which are very common in Karamoja. The metallic products obtained are used in infrastructure projects such as construction of railways, roads, buildings and making utensils and other equipment outside Karamoja.

It should be noted that even though there is no oil in Karamoja region, the global oil industry indicated that Uganda is the 'hottest inland exploration frontier' (Ink, 2009:16). Certainly, apart from oil in the Albertine Graben, Karamoja region is very rich with various minerals like gold, chromite, copper, gemstones, limestone and marble that covers '6,876.92 square miles for Exclusive Mineral Exploration and 
Location Licenses,' yet some other areas are not surveyed (Rugadya and Kamusiime 2013:19). Currently, there are more than '21 licensed...' private companies exploring and mining minerals in the region (Adoch and Semakula, 2011:12). Based on the 2010 mining industry data; of 27,700 square $\mathrm{km}$ of Karamoja land, $40.8 \%$ $(11,300 \mathrm{~km})$ is a protected area (Uganda Wildlife Authority (UWA), 2010 cited in Rugadya and Kamusiime 2013). The National Forest Authority (NFA) of Uganda is currently managing forest reserves that cover a total area of '3,222 square kilometres (or 322,210 Hectares), which equal to 11.6\%' (Rugadya and Kamusiime 2013:16). However, it has been observed by many Karamajong and some civil society activists that most protected areas, in the name of conservation reserves, are mineral rich areas that are only accessed by some government officials. None of the primarily pastoralist Karamajong own land; however, some elders among them own some land amounting to $10 \%$ square kilometres (Rugadya and Kamusiime 2013:2). Presently, mining companies, especially those owned by the Chinese and Egyptians, have so far taken a big piece of land from the Karamajong, which is estimated to be $30 \%$ square kilometres (Hinton et al. 2010). Currently, Karamoja region is going through very radical transformations, which cannot leave the environment and the local community at the same level.

\section{Theoretical framework}

This paper draws on the theory of environmental Kuznet curve; it assumes that a rise in countries' per capita income is related to the environment and social inequality (McCarthy and Tacconi 2011; Stern, 2004). It postulates that environmental quality declines until an optimum point is reached, then it improves and the cycle continues as per capita income increases; this affects ecological and social settings in a ' $U$ shape...' as illustrated below (McCarthy and Tacconi 2011).

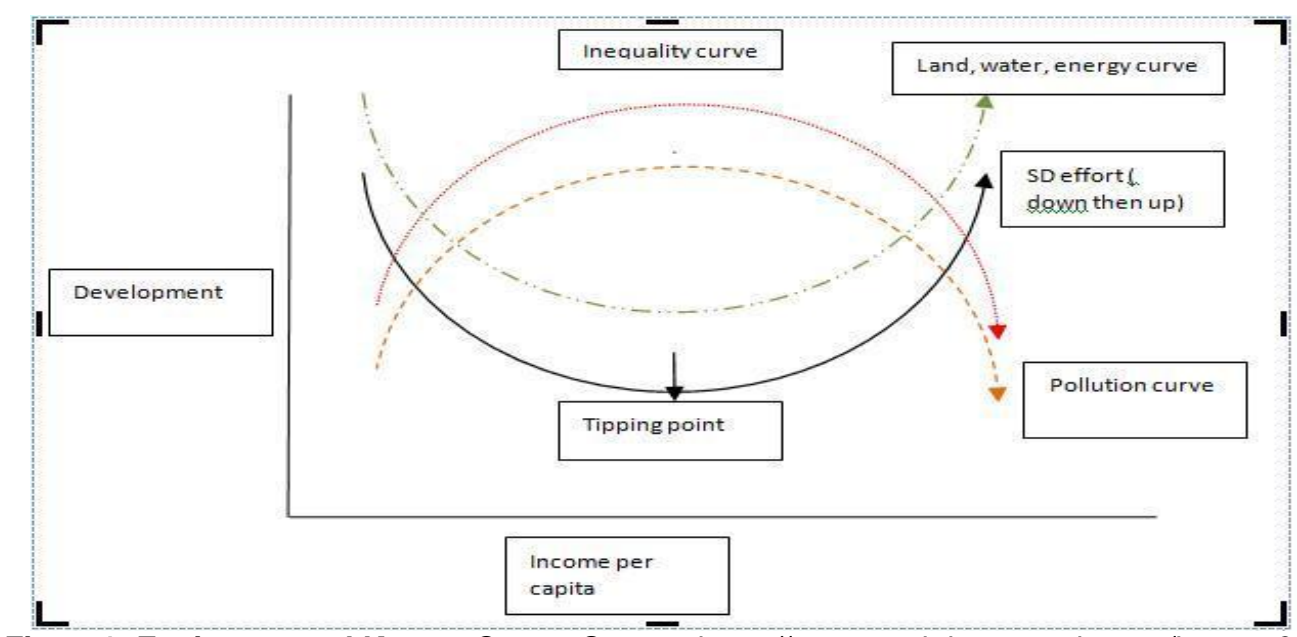

Figure1: Environmental Kuznet Curve. Source: https://encrypted-tbn3.gstatic.com/images?

The inequality curve is brought by a conflict theory which Coser (1957) defines as that 'struggle over values, power and resources in which the aims of the opponents 
are counteracted.' In this theory, the strong ones aim at eliminating their rivals while injuring the weak in the process. The theory stimulates social change, encourages innovative ideas and upsurges and centralises state power during times of intense conflict. Unfortunately, power is at the core of all social relationships, this creates a tendency of taking advantage of the poor through creation of social classes (Lepird et al. 2013). The study also draws on the environmental security framework propounded by Homer-Dixon (1994) illustrated below.

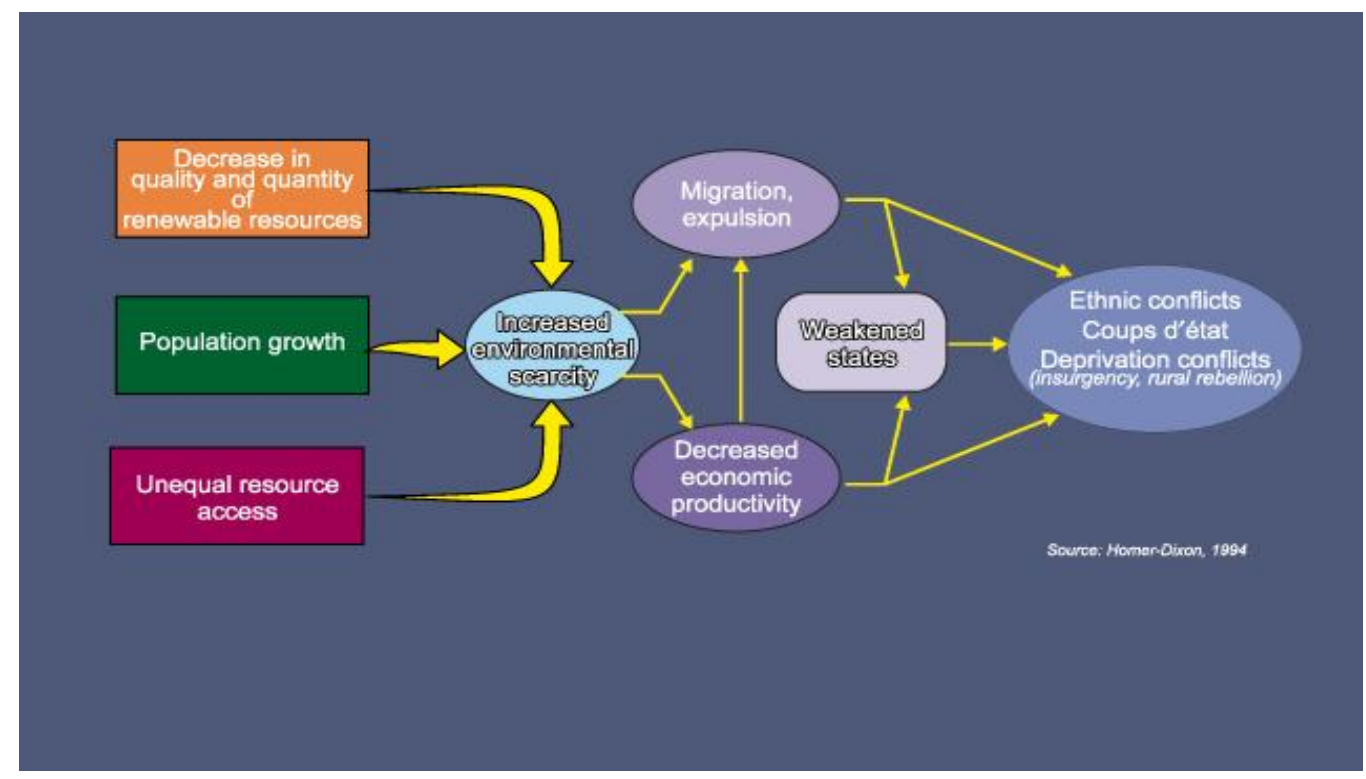

Figure 2: Environmental Security Framework. Source: (Homer-Dixon, 1994)

This framework examines the role of environmental change with regard to conflict. Homer-Dixon established this theory to analyse the role of environmental scarcity (supply induced, demand induced, and structural scarcity) in causing, starting and prolonging conflicts. He argues that resource scarcity at the community level might stir conflicts, especially when people start struggling for the few resources. He continues that in supply induced scarcity, though the demand is stable, the reduction in the amount or quality of the resource translates into scarcity for a user. Therefore, as mining concessions increase in Karamoja, the environment is affected and automatically ecological services decrease. This supply induced scarcity does not only impact on societal progress, but also on environmental stability.

On the other hand, demand induced scarcity is a result of increase in demand. This can happen due to population growth, due to increased demand from industry and production processes. However, increase in demand can be observed without population increase. For instance, if a particular resource becomes scarce in some part of the world, demand for it increases in another place. For this reason, demand for marble has increased in East Africa. Therefore, the presence of marble in Rupa Sub- 
county (Moroto District) and in Amudat District has influenced many people to flock to Karamoja region in search of marble.

In addition, structural scarcity occurs when a powerful group denies access to a resource by a less powerful one. This implies, the amount of the resource is still the same as before, yet the supply has not changed in real numbers. Though demand remains stable, scarcity of the resource is felt by the less powerful group. For instance, in Rupa Sub-county, DAO Mable (a quarrying company) forced the locals off the quarrying activity from which they earned a living, by blocking their access to the quarry with big boulders. (As explained by the Youth leader from Loputhaka Youth mining group in Rupa Sub-county, 2015).

Exploration and mining activities were the independent variables while the weak government policies were intermediate variables. The weak policies control the relationship between private companies and the Karamajong artisanal miners. In other words, mining activities work hand in hand with government policies because it is the government that contracts private companies. Similarly, ecological and social impacts, which can result into a conflict, were dependent on mining activities. The outcome of this whole interaction can be environmental insecurity or environmental scarcity. The measurement of variables was done using the criterion-related validity, which evaluated the evidence that was ascertained from emergence of human rights violation in Karamoja region as a result of mining activities (Kimberlin and Winterstein, 2008).

The target population in this research was the Karamajong, miners (private companies both international and local) and Ugandan government leaders starting from the local council leaders (LC I - LC V). The sample size included 250 respondents who were contacted using purposive sampling technique.

\section{Findings and discussion}

\section{History and benefits of mining}

The findings were obtained from the three districts, namely Moroto, Nakapiripiriti and Amudat. It should be noted that Karamoja has different ethnic groups namely, the typical indigenous (Tepeth) who live on top of mountain Moroto and the Matheniko who live in the lowlands of Moroto District. The Matheniko are the only ones involved in gold mining and marble quarrying across the District. One of the local government officers in Nakapiripiriti narrated that within Karamoja region, gold mining begun in Kaabong District in the 1980s. This was done by the hunger stricken Dodoth $^{2}$ migrants who had migrated from Kaabong to the present day South Sudan. While in South Sudan, as a relief from famine, the Dodoth were taught how to locally

\footnotetext{
${ }^{2}$ A Karamojong tribe from Kaabong District
} 
mine gold, which was obtained in the flowing waters of White Nile. It is currently estimated that between 700,000 and 1,000,000 people in Karamoja region are involved in marble and gold mining (Nakapiripiriti Local Government Database accessed on October 23 2014). Though gold was discovered in Moruita Canaan Village as early as 2004, four men began mining it in 2013 (Interview with a Nakapiripiriti District official on 23 October 2014). According to one of the local miners, this activity was embarked on as a temporally solution to poverty in the communities. However, it is now a lucrative business which has attracted artisanal miners from within and outside Karamoja. Unfortunately, local people within Uganda buy gold from the Karamajong at a low price. One of the youth leaders, Loputhak, lamented:

We are trying to get something for our families, but men who have money are spoiling our business, because they give us very little money, which cannot sustain us. We mine gold in a group, by the time we share it, we realise it's not enough for us and our treasury

(Interview held in September 2014 in Rupa Subcounty, Moroto district)

During mining, there are shared roles between men and women. Men and boys go down the gold pits while the women and girls fetch water and sieve the soil to obtain gold particles. A similar situation obtains in marble quarrying: men do the harder tasks while women break the smaller rocks or boulders. Owing to the cultural values in Karamoja region, it seems mineral resource mining and social structural changes have, in some way, put men and women together. One of the women miners commented that the challenging situations have brought both men and women together since the disarmament period.

Additionally, marble quarrying at Apetai and Tapach commenced in 2002 after an agreement between the local people and the Tororo Cement Factory coordinators. One of the elders confirmed that this activity begun as a result of disarmament, because the locals could not go back to raiding cattle and an epidemic (East-cost fever and foot and mouth disease) had robbed them of many cattle. Having been left with no demanding work, they resorted to marble quarrying which rewarded them with a meagre income to feed their families, especially during the dry period. One of the elders said that the people from Tororo Cement used to give them UGX20,000 per heavy truck until the locals complained and the fee was raised to UGX30,000. After a hassle the fee was further raised to UGX150,000. One of the elders lamented that "I pray that it rains hard so that the roads are impassable thus, trucks can stop coming to us". They now want to fully involve themselves in subsistence farming to improve their food security.

There are many challenges associated with artisanal mining in the region; one of them is associated with health in the mines. Health issues in the mines include boils and deep wounds acquired in the process of mining. The health centres are not near to mining sites in case of an emergency. Nevertheless, the government of Uganda has 
done its best to conduct health awareness campaigns aiming at helping the Karamajong to improve on their health status. However, there are some people who have never accessed government health services. Beside their feeder roads being rugged and bumpy, the heavy trucks of marble have made them worse and during the rainy season, all roads are impassable. One elder commented, "Since nature has provided, we have embraced it; she will be merciful to us soon". With the long drought, the ground becomes rocky hard, hence mining becomes very difficult. However, those with better machines are able to continue mining. During the rainy season, the open pits are flooded, sometimes causing death. Though mining comes with great achievements, in Nakapiripirit District its continuation has increased prostitution, hence the spread of HIV/AIDS. The District Health Statistics of 2014 show that $5.1 \%$ of the population has been infected with the disease (Interview with the Resident District Commissioner of Nakapiripirit on 23 October 2014). In addition to high crime rate, bureaucratic tendencies have led to corruption and increased conflicts among community elders.

The Guardian (2014) mentioned emerging severe human rights violations in Karamoja region by private companies. The same source also called for government reforms in the mining act and regulations to include respect of indigenous people's rights in the region as a response to the comment of one of the elders. The comment was as follows:

We want to see our natural resources exploited but our people should not be. Pastoralism lives here, we are pastoralists. The land looks vacant but it is not

(Elder's comment as seen in the Guardian of 4, February 2014).

Despite the fact that Karamoja region is experiencing human rights violations, those involved in exploration and large-scale mining are not paying heed because their benefits are substantial (Human Rights Watch Report, 2014). That is why it is still difficult to believe that mining in Karamoja can transform the region.

According to some local government leaders in the three districts, the Government has advised the local communities interested in mining to form small groups to enable it send assistance via the small groups' leadership. More still, the government promised to build a cement factory in Amudat District to provide employment for the local people (the Pokot). Another Local Government officer declared that, there are more than 35 companies that have partitioned the region where they have explored minerals. In Rupa, some youths are contented with artisanal miners mining side by side with the private companies. Moreover, the presence of minerals has attracted decentralisation of public services like water (boreholes), schools, health centres among others. In Tapac sub-county, local government leaders work hand in hand with the local communities. There is information sharing, consultation, systematic problem solving, justice, peace and security. Currently, there is unity among artisanal mining communities for both men and women. The little money obtained is shared among the 
miners in groups especially Loputhaka Youth Group. However, some miners still face enumerable challenges in the three districts.

The people involved in the mining business start with constructive ideas; however, as the business grows, the positive aspect of sustainable development is completely forgotten (Esteves, 2008). That is why hazards which indigenous people faced in South Africa, Australia and Central America were a result of "... nature of the labour process, the technologies of production, the rapacity of employers, and the limitations of state regulation" (McCulloch, 2008:8). What happens with labour in mines is the fact that employers come with their experts who then perform the relatively easier role of supervision while the labourers from the host community do the arduous task. To make matters worse, employment for people in the host communities does not involve contracts where one could know the conditions and terms under which he/she is employed. This is due to the fact that the host communities are not respected by many private companies (Joris van de Sandt, 2009). In this regard, some Karamajong are involved in mining activities especially the youth and women though with meagre benefits. One of the elders said:

\begin{abstract}
Some of our children have managed to get jobs in some of the mines of the private companies but are not paid enough. Those working in marble quarries with DAO Company are facing terrible conditions and they come back home, sick with big wounds on their legs. Many of them have bad coughs yet we cannot access health centres for treatment

(Interview with one of the elders in Rupa Sub-county, Moroto district on 23 October 2014)
\end{abstract}

While employment is depicted in the region, the payments for these employees are insufficient and the working conditions are unbearable. Similarly, in industrial mining, working conditions for employees become horrendous; employees get low wages and salaries, which are often delayed. Hilson (2013:51) discovered that "the unskilled and illiterate majority of Frafra migrants" were drawn into the "low-income section of the labour force in Accra". This situation does not favour the livelihood of the vulnerable population. However, it could be beneficial when the unskilled and illiterate are taught skills which can improve on their income and livelihood.

Furthermore, Reutter (2003) describes how four towns of Uravan, Grants, Moab, and Jeffrey in Colorado United States of American, had shared economic dependence, but were later on doomed after the discovery of Uranium. He argues, "Although the government encouraged individual prospectors to find uranium, only well-capitalised corporations could successfully mill the "yellowcakes..."' (Reutter, 2003:9). Governments in developing countries encourage individual miners claiming that the revenue collected would assist in public infrastructural development, yet it is not always the case. Paganelli (2011) argues that government's move towards social security is basically, "...for the defence of the rich against the poor..." (Adam Smith's (1751:232) cited in Paganelli (2011). This explains why presently mineral resources are a catalyst in the creation of conflicts in the global south. 
According to Hinton et al. (2011), there are three categories of miners. The first ones are the registered and licensed miners who explore and mine minerals on a large scale. The second category includes Small Scale Miners (SSM) who operates on a small scale and is licensed. At sometimes, these miners are not registered; they act under the umbrella of the registered ones. They go into mining for its lucrative aspect and make it a competitive venture with the large scale miners. The third category includes artisan miners who use rudimentary tools and basically mine minerals for self-sustenance. However, the first two of the three categories are financially empowered while the local artisanal miners do not have enough money to obtain a licence and go into mining concessions. Although there are no large-scale miners in Karamoja, those who are already licensed and have a contract are able to maximise their rewards by subjugating the financially weak Karamajong. It is for partly this reason that the number of licensed mining companies has been on the rise since 1999 . For instance, Figure 1 shows how the mining enterprise began picking momentum between 1999 and 2010.

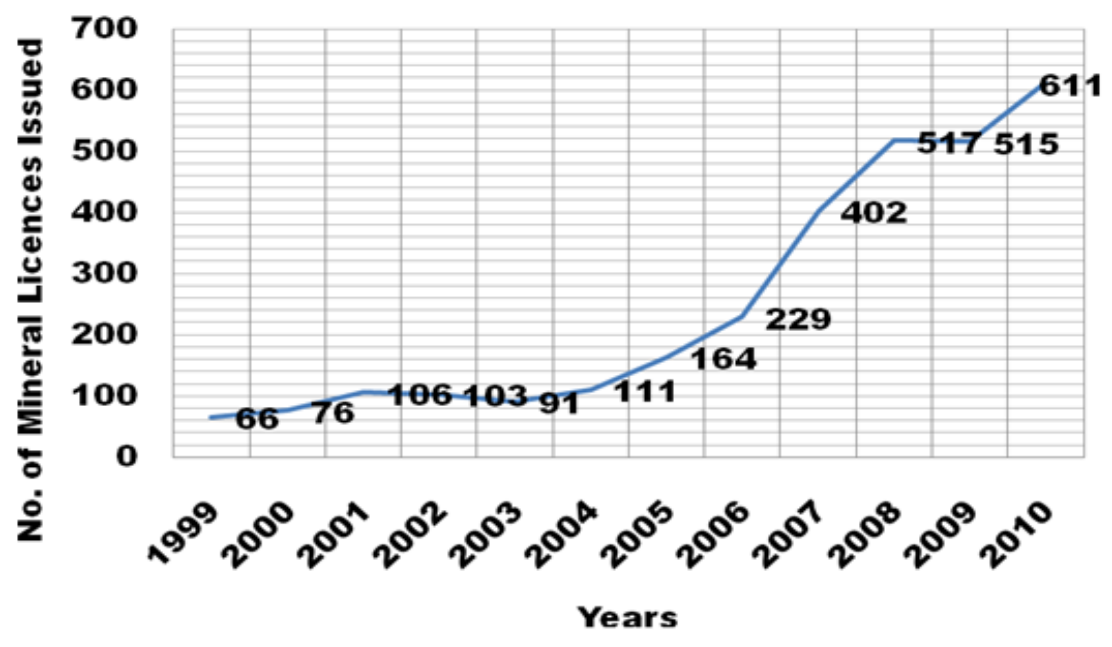

Figure 1: Mineral resource exploration and mining in Karamoja between 1999 and 2010 Source: http://cod.mofa.go.ug/images/image026.png

The figure also shows that issued licenses increased to 611 in 2010. This could imply that if all factors remain constant, mining companies could be increasing annually, which might raise the revenue and GDP of the country. Yet with corruption in the government, an increment in GDP might be an elusive idea. On the other hand, as mining concessions increase, there is a similar increase in both the number of new discoveries of mineral resources and licences for contracts. Consequently, mineral resource exploration and, to some extent, subsistence farming are slowly but steadily replacing pastoralism as a source of livelihood among several Karamajong communities. 
According to the Statutory Instrument of 2004 No. 71 individuals or groups have regulations to follow in applying for an exploration licence. This is done through the right channels of the government. In that case, the licence gives individual companies a right to operate in the region mining business in any specified piece of land. Accordingly, as exploration and mining activities take root, game reserves and national parks within the region, such as Kidepo, are gradually getting encroached on especially when mineral resources are discovered in various spots within the game reserves. For that reason, private companies are more interested in the mine business than biodiversity conservation and promotion of livelihood of local people. Based on the current trend of exploration and mining activities, the state seems to have a big hand in this concession. Therefore, as mining concessions rise, ecosystem services will automatically reduce leading to biodiversity extinction.

According to the Uganda Bureau of Statistics (2010) as can be seen in the figure 2 below, mining is a profitable enterprise which has practically improved especially between 2005 and 2010. However, the mining growth rate is somewhat diminishing and irregular despite the discovery of different prospective areas with mineral resources. This implies that many people are into mining concessions and the revenue collected is practically retained by individuals.

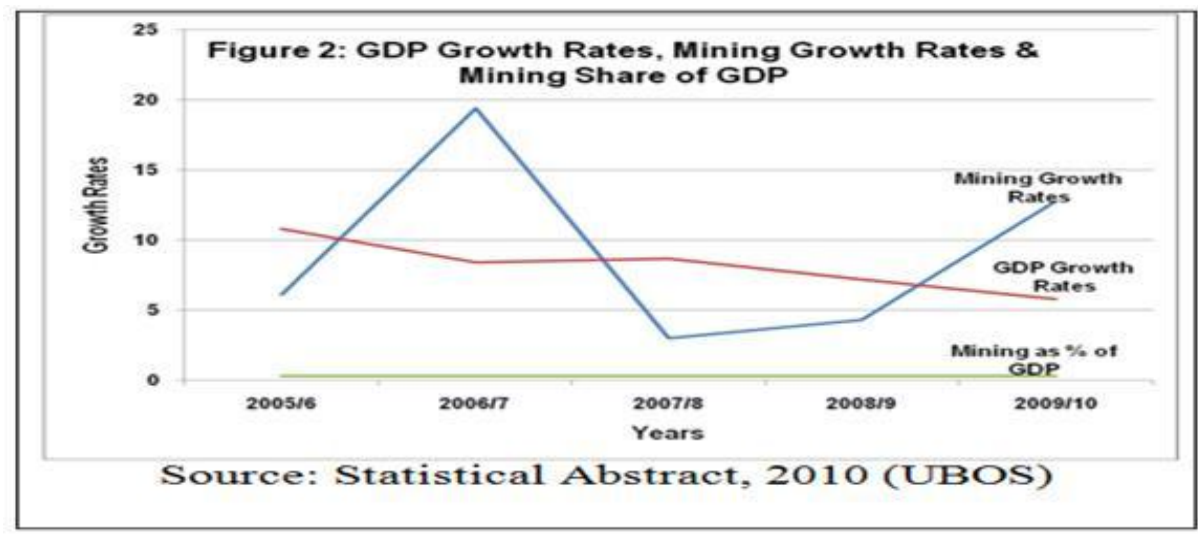

Figure 2: Growth Rates, Mining growth rates \& Mining Share of GDP

\section{Health impacts}

It should be noted that mines across the globe not only cause conflicts among employees, but also chronic diseases due to bad working conditions as a result of 'inhaling asbestos, miscarriages, skin diseases' (Joris van de Sandt, 2009:12). In many cases, both temporarily and terminally ill patients are not given proper health care or packages whenever they are laid-off. Yet, in 1954, the UN conference encouraged that "...compensation should be in accordance with the 'triple standards' that is 'prompt, adequate and effective'..." (Schrijver, 1997:58). Fortunately, the artisan miners of South Africa succeeded in court and they were compensated. It was the "... first time South African miners have succeeded in a common law action 
against a parent company..." (McCulloch, 2008:8). Mining is an important economic activity, but its implications need to be addressed before its commencement.

\section{Local community participation in mineral resource mining}

In some countries, community participation in development helps in building human and social capital, which in turn facilitates decision making and leads to potential sources of financial capital and thus physical capital development (Esteves and Vanclay, 2009). In the developing nations, the key element and core value of rural development derives its strength from community participation, because it creates trust among people and maintains unity. To stress the point of local people contribution, Arnstein (1969) argues that citizens' participation in the development process is 'power', which eliminates all traces of conflict. She emphasises grassroots' involvement in decision making processes, such as 'setting goals and objectives including resource allocation' and sharing community development activities (Arnstein 1969:1). This aspect gives them a sense of belonging and responsibility of full participating in transforming their community.

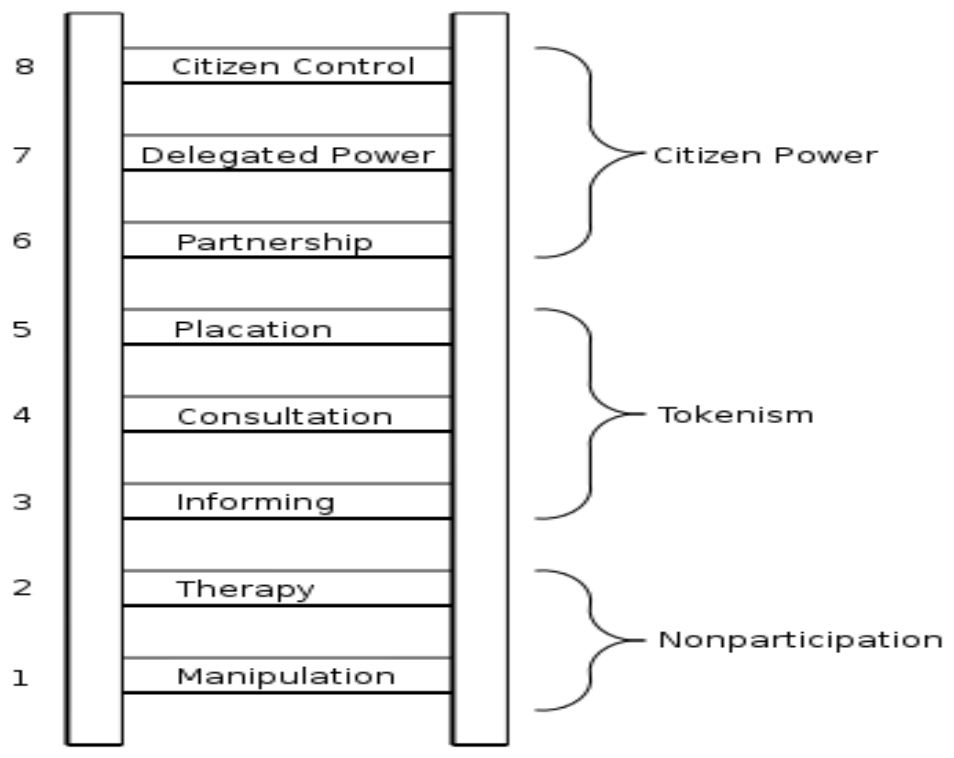

Figure 3: Sherry Arnestein's Ladder of Participation adopted from Webmaster 2006 Source: (Arnestein, 1969: 216-224)

Arnestein's ladder of participation shows stages of community involvement, which lead to community ownership of resources and autonomy in community transformation. The ladder starts with manipulation up to the last level of citizen control. Though manipulation is not the best way of handling people at the grassroots' level, this can help to attain the level where locals are informed about what is happening in their community. However, Baker and McClellan (2003:53) disagreed that local participation policy works only on the 'procedural level' but fails on the 
'substantive level.' For instance, when community participation in environmental assessment was tried among the First Nation people in Colombian mines, results did not conform to the expectations of mine administrators. As a result, informing people of the activities in mining through meetings or consultations often does not influence them to have a sense of ownership of the mines.

However, sensitising and involving the community can lead to a change of mindset; thus, a smooth road to sustainable development following the positive aspects of protection and preservation of all living and non-living things in the ecosystem. Powell (2010:9) cited in Bevan (2008:21) points out some activity done by the government particularly on land reallocation, which has increased 'firepower' yet with minimal state security that has pushed an 'already fragile pastoral system out of equilibrium.' It is therefore, difficult to relocate people who were already used to pastoralism without enough assistance and much needed security considering that disarmament regulated the use of firearms. This insecurity encourages people to get a supply of weapons from neighbouring countries and the outcome can be disastrous.

Nonetheless, community involvement in resource management can reduce stress between indigenous people and the mining companies. Filer and Macintyre (2006) agreed with Arnstein (1969) that in Papua New Guinea, mining was one of the activities, through which people at the grassroots could gain wealth. This was an action done by indigenous people empowering themselves in protecting their mines. Consequently, the autonomy of local people is a necessity for achieving ecologically friendly mining activities and sustainable development. The challenge is about who gives autonomy to people in governing and managing mineral resources.

While participation creates equilibrium in mining, absence of transparency in the process intensifies conflicts. Filer and Macintyre (2006:215) argued that, some mines existed for ages in Fiji but were not productive, because they contributed only ' $2 \%$ of the GDP.' This implies that during unproductive times, when minerals are insufficient; mines are fully exploited while when mines are fully stocked, they are not well exploited. Nevertheless, labour can be sufficient for infertile mines and exploit them, yet the challenge remains on those handling mineral extracts. Consequently, absence of transparency in mining activities leads to delay in the development process, which could transform the community. In addition, poor or underdeveloped road and communication network can disrupt mineral resource mining leading to inefficiency in mining regardless of the amount of natural stock of minerals beneath the earth. When miners work hand in hand with the host communities in the development process, some positive aspects are manifested (Esteves, 2003). In this case, the autonomy of the Karamajong in mining activities is at stake, which can end up increasing conflicts. Thus government's act of contracting mining companies without consulting the Karamajong can reduce their trust in it.

Esteves (2008) contends that large-scale mining companies have not included local communities in their mining business thus, they only cooperate with governments and isolate host communities, which usually escalates social conflicts. 
To promote co-existence between host communities and mining companies, corporate social responsibility is a prerequisite by the mining companies (Newbold, 2003).

Mineral resource mining in Karamoja is in its early stages; it cannot be compared to some states in developing countries, for example, in the Latin American countries like Guatemala. This is due to the fact that it has either not been fully explored, or the areas that have been explored, have been mined in haste. Therefore, this haste activity has clear manifestations of tension between private companies and the Karamajong especially in Rupa sub-county. The tension could be as a result of mines owned by private companies, which are licensed by the government and thus, artisanal miners who are not licensed are considered to be trespassing in the explored and licensed mining areas.

Additionally, evicting the Karamjong from their pastoral lands proves that individualism is overtaking the community aspect, which used to bring people together with the aim of eradicating poverty out of the region (Adoch and Semakula, 2011). Nevertheless, what is on the ground is not designed to transform the area but rather to grab Karamoja land in order to satisfy individual interests. In the Guardian (2014), one of the Karamajong a Dodoth elder from Sidok, Kaabong Town said:

There is nothing bad about companies coming, but what we hate is the way they come in, don't show us respect, and don't show us the impact and the benefits of their work for my people.

(Elder's comment as seen in the Guardian of 4, February 2014)

If the current situation persists, then the Karamoja mining concessions are on the road of causing social conflicts most especially if host communities are not mutually consulted in the development process (Andrew, 2003). To avoid this, voluntary programmes that allow positive participation in community development by mining companies are very crucial. Another elder in Dodoth, Kaabong with grief argued that:

\footnotetext{
If companies come, as a visitor comes to your home, they should first consult you. They should consult us; make us an offer, before they start work... Instead, they go to the government only, they don't come to us... You can tell whether a government is good by whether they consult with us [in making decisions that affect us].

(Elder's comment as seen in the Guardian of 4, February 2014)
}

Consequently, there is a need to educate private companies on issues related to community development and environmental protection, which is paramount in developing the region. However, by show of example, if the government respects the rights of the Karamajong, then those who enter into the mining business will have no option but to also respect them. Although sometimes as the mining picks momentum, everything is forgotten; as a result, the host communities suffer. On the other hand, 
Esteves (2008:1) challenges that most mining companies have failed to fulfil their mining obligations with regard to 'social development.' Nevertheless, there is a distinction between involvement in mining and corporate social responsibility, which fosters promotion of the common good. However, those involved have a challenge of sticking to ideas, which are productive and pro-people (Owafiokundi, 2009). This infers that the divergence from the original objective of mining can intensify conflicts within mines and the whole locality ends up in chaos which in itself can lead to environmental degradation.

\section{Mining activities versus biodiversity conservation}

Wildlife conservation is part of Uganda's goal to improve and promote sustainable development and harness finances from tourism. However, with laxity in the Ugandan environmental law and ministry of environment, the protected areas shown in the Table 1 below will soon be encroached on during explorations. It is not only wildlife reserves, but also forest reserves. For instance, in 2002 a Libyan investor sought a forest reserve in Pian-Upe Wildlife reserve for agricultural purposes through the government, but was not successful because the local leaders learnt about it and opposed it. On the other hand, some 'investors' manipulated local people and took fertile lands from them after discovering the treasure of different minerals in that land. In the years to come, some conserved areas will only remain on paper.

Table 1: Wildlife Protected Areas in Karamoja

\begin{tabular}{|l|l|l|}
\hline Wildlife Protected Areas & $\begin{array}{l}\text { Size in } \\
\text { sq.km }\end{array}$ & Location \\
\hline National Parks & & \\
\hline Kidepo National park & 1,436 & Kaabong \\
\hline Wildlife Reserves & & \\
\hline Pian Upe & 2,043 & Nakapiripirit \& Napak \\
\hline Matheniko & 1,753 & Moroto \& Kotido \\
\hline Bokora Corridor & 1,833 & $\begin{array}{l}\text { Kotido, Abim and } \\
\text { Moroto }\end{array}$ \\
\hline Community Wildlife Areas & & \\
\hline Amudat & 2,053 & Amudat \\
\hline Iriri & 1,046 & Napak \\
\hline Karenga & 956 & Kaabong \\
\hline
\end{tabular}

Source: Adapted from Uganda Wildlife Authority Planning Unit, 2011

It is widely known that the increase in mining concessions negatively impacts the ecosystem because the miners encroach on the habitat of the whole biodiversity. As a consequence, they migrate to other places and often die on the way. Furthermore, cleared places have exposed the biodiversity to additional problems that can lead to their extinction (Houdet et al. 2014). This is due to the fact that their habitat has already been destroyed. 
On top of biodiversity loss, soil erosion is a huge challenge; artisanal miners have dug everywhere and the whole land is exposed to huge pits. On the other hand, largescale miners have cleared a big piece of land, which makes the land unproductive. When it rains, the land is bear and the floods clear everything down the hill making farming difficult. In addition, land clearance has increased timber and wood collection, which implies that there is a danger of extinction of indigenous tree species. This too reduces the ecosystem services and makes the situation worse for the survival of the host communities in the region, especially the Tebeth.

\section{Conclusions}

Mineral resource mining is a progressive venture; however, it destroys the environment and affects host communities' livelihood. The environment is our mother and when humans hurt her, she retaliates and the bitter consequences are experienced by both the rich and poor. Besides, the government's pursuit of economic development at the expense of the ecosystem is not right because it leaves a long-term negative impact on the environment and the people. In effect, transforming Karamoja region through mining is an elusive idea, which needs to be re-examined in favour of the environment and the local community before mining concessions pick momentum. Therefore, it is high time the government of Uganda begins re-thinking mining in Karamoja before the atrocities committed by mining companies to the Karamajong distort their lives and livelihoods.

As matter of fact, mineral resource explorations are still going on in Karamoja and other minerals are yet to be discovered. Therefore, before licensing private companies, there is an urgent need to include the local people in decision making processes on matters affecting them. Needless to say that the participation of the local community is the basis of development of rural areas in the global south. Instead of concentrating on providing low employment in mining, promoting high profile employment could be a potential aspect in improving working conditions of the Karamajong. Moreover, the government has a duty to create and promote social development ventures in addition to artisanal mining. It is very clear that mineral resource mining in Karamoja region is in its infancy, yet the situation is not favourable for the Karamajong. What will happen if this trend of events continues like this? Given that, the environment is already punitive, what should people expect in future? It is also true that the government is gradually transforming the region with improved agricultural activities. However, it is not easy to change the mind-set of the pastoral community into farmers, even though a few are engaged in subsistence farming and artisanal mining.

\section{Recommendations}

Based on the findings, discussion and conclusion, mining concessions are capable of becoming a big project in future and they have the potential of changing the livelihoods of the Karamajong people. I therefore, I recommend the following: 
1. The government of Uganda should reform the Mine Act of 2003 in favour of indigenous people so as to achieve sustainable development. When the Karamajong are favoured and included as primary stakeholders, it will create autonomy and harmony in the region, thus a smooth co-existence. Furthermore, it will help in the sustainable use of natural resources and environmental conservation.

2. It is the government's responsibility to protect and support its citizens. Therefore, government should find suitable employment opportunities for the natives and eliminate human rights violations carried out by private companies. The manipulation of the Karamajong should stop, but consultation and cooperation must be encouraged in order to promote active participation of the local people for the betterment of the region.

3. There is need to put in place a memorandum of understanding between artisanal and large-scale miners in order to make the venture more formal and moving towards development and avoid eventual and conflicts.

4. All artisanal miners appeal to the government to provide better tools for mining to avoid the dangers incurred such as diseases and death among others.

5. The Uganda Police should work hard to maintain security in order to control the crime rate.

\section{References}

Adoch, C. \& Ssemakula, E., 2011. Killing the goose that lays the golden egg: An analysis of budget allocations and revenue from the environment and natural resource sector in Karamoja Region. ACODE Policy Research Series, No. 47, 2011. Kampala.

Ager, S., 1998. Omniglot: The Online Encyclopaedia of Writing Systems \& Languages.

Andrew, J. S., 2003. Potential application of mediation to land use conflicts in smallscale mining. Journal of clear production 11(2) 117-130

Arnstein, S.R., 1969. A ladder of citizen participation. Journal of the American Institute of planners, 35(4) 216-224

Baker, D. C. \& McLelland, J. N., 2003. Evaluating the effectiveness of British Colombia's environmental assessment process for first nations' participation in mining development. Environmental Impact Assessment Review 23(5) 581-603.

Coser, A.L., 1957. Social Conflict and the Theory of Social Change. The British Journal of Sociology, 8(3) 197-207. [Online] Available From: http://www.csun.edu/ snk1966/Lewis\%20A\%20Coser\%20Social\%20Conflict\%2 0and\%20the\%20Theory\%20of\%20Social\%20Change.pdf [Accessed 23 February 2015]

Esteves, A. M., 2008a. Mining and social development: Refocusing community investment using multi-criteria decision analysis. Resources Policy 33(1) 39-47

Esteves A. M., 2008b. Evaluating community investments in the mining sector using multi-criteria decision analysis to integrate SIA with business planning. Environmental Impact Assessment Review 28(4) 338-348 
Filer, C. \& Macintyre M., 2006. 'Grass roots and deep holes: Community responses to mining in Melanesia'. The Contemporary Pacific Article 18(2) 215-231

Fortuna, M.A., Krishna, A. \& Bascompte, J., 2013. Habitat loss and the disassembly of mutualistic networks. Oikos 122(6) 938-942

Guardian, 2014. Mineral deposits in Uganda's Karamoja heighten human rights abuse. Mines and Communities. 04 February 2014 [Online] Available From: http://www.minesandcommunities.org/article.php?a=12555 [Accessed 20 January 2015]

Hilson, G. \& Murck, B., 2000. Sustainable development in the mining industry: Clarifying the corporate perspective. Journal of Resources Policy 26(4) 227-238

Hilson, G., 2013."Creating" rural informality: The case of artisanal gold mining in Sub-Saharan Africa. SAIS Review 33(1) 51-64

Hinton, J.J., 2011. Gender differentiated impact and benefits of artisanal mining: engendering pathways out of poverty. Columbia, University of Vancouver

Hinton, J., Kabongo, I., Kabiswa, C., Okedi, J., \& Mbabazi, R., 2011. Baseline Assessment of the Mining and Minerals sector in Karamoja, Uganda: Development opportunities and constraints. Ecological Christian Organisation

Homer-Dixon, T.F., 1994. Environmental scarcities and violent conflict: Evidence from cases. International security, 19(1) 5-40

Houdet, J., Muloopa, H., Ochieng, C., Kutegeka, S., \& Nakangu, B., 2014. Cost benefit analysis of the mining sector in Karamoja, Uganda. IUCN Uganda

Ink, D. R., 2009. Harnessing oil for peace and development in Uganda investing in peace. International alert, Issue No. 2, Print House Kampala.

Kimberlin, L.C. \& Winterstein, A. G., 2008. Validity and reliability of measurement instruments used in research. American Journal of Health-System Pharmacists 65(23) 2276-2284

Kronenberg, J., \& K. Hubacek, K., 2013. Could payments for ecosystem services create an "ecosystem service curse"? Ecology and Society 18(1) 10. [Online] Available From: http://dx.doi.org/10.5751/ES-05240-180110 [Accessed 23 March 2015]

Lepird, E., Canny, S., \& Saldanaet, M., 2013. Conflict Theory. Public Lecture.

McCulloch, J., 2008. Surviving blue asbestos: Mining and occupational disease in South Africa and Australia Transformation: Critical Perspectives on Southern Africa, 65(1) 68-93.

McCarthya, S. \& Tacconi, L, 2011. The political economy of tropical deforestation: Assessing models and motives. Environmental Politics 20 (1) 115-132

McCulloch, G., 2005. Documentary research in education, history and social sciences. London and New York, Rutledge Falmer, Taylor \& Francis Group.

Nangiro, S. \& Davies, J., 2013. Kotido pastoral development program: An overview of Oxfam GB's work in North-eastern Uganda. Ministry of Karamoja Affairs, Karamoja Data Centre

Newbold, J., 2003. Social consequences of mining and present day solutions: Region II in Chile highlighted. Sustainable Development, 11(2) 84-9

O'Faircheallaigh, C., 2004. Evaluating agreements between indigenous peoples and resource developers. In: Langton, M., Palmer, L., Tehan, \& M., Shain, K. (Eds.), 
Honour among Nations: Treaties and Agreements with Indigenous Peoples. Melbourne University Press

Office of the Prime Minister, 2010. Karamoja action plan for food security (20102015), Kampala

Peeters, J., 2012. The place of social work in sustainable development: Towards ecosocial practice. International Journal of Social Welfare 21(3) 287-298

Paganelli, M. P., 2011. Adam Smith and economic development: theory and practice. Work in Progress. [Online] Available From: http://www.anpec.org.br/downloads/Encontro\%202011_texto\%20Paganelli.pdf [Accessed 23 March 2015]

Powel, J., 2010. A report on Karamoja literature review. Safe World. [Online] Accessed From: http://www.saferworld.org.uk/Karamoja\%20A\%20literature\%20review.pdf [Accessed 23 March 2015]

Reutter, M., 2003. Yellowcake Towns: Uranium mining communities in the American West (review). Enterprise \& Society Article 4(2) 389-390

Rugadya, M.A. \& Kamusiime, H., 2013. Tenure in mystery: The status of land under wildlife, forestry and mining concessions in Karamoja Region, Uganda. Nomadic Peoples 17(1) 33-65.

Schrijver, N., 1997. Sovereignty over natural resources: Balancing Rights and Duties. Institute of Social Studies, The Hague, Cambridge University Press.

Stern, D.I., 2004. The rise and fall of the environmental Kuznets curve. World Development, 32 (8) 1419-1439

Solomon, F., Katz, E. \& Lovel, R., 2008. Social dimensions of mining: Research, policy and practice challenges for the minerals industry in Australia. Resources Policy, 33(3) 142-149.

The Government of Uganda, 2004. Statutory instruments supplement No. 38. The Uganda Gazette No. 57 Volume XCVII of 2004. Entebbe, Uganda Printing and Publishing Corporation

Uganda Bureau of Statistics, 2010. Growth rates, mining growth rates \& mining share of GDP. [Online] Available From: https://www.google.com/url?sa=i\&rct=j\&q=\&esrc=s\&source=images [Accessed 10 September 2015]

$\mathrm{UN}, 1992$. Report on the conference on environment and development at Rio de Janeiro, pp 3-14.

UN, 2008. Declaration on the rights of indigenous people. [Online] Available From: http://www.un.org/esa/socdev/unpfii/documents/DRIPS_en.pdf [Accessed 23 March 2015]

USAID, 2006. Final report on Uganda biodiversity and tropical forest assessment. EPIQ II Task Order no. 351, USAID.

Uwafiokundi, I., 2009. Assessing corporate-community involvement strategies in Nigerian oil industry: an empirical analysis. Resource Policy 34 (3) 133-141

van Sandt, J.J., 2009. Mining conflicts and indigenous peoples in Guatemala. Cordaid.

World Bank, 2013. Developing Uganda's mining sector; empowering artisans, streamlining regulations, and extending technical assistance. World Bank 
Worall, R., 2009. Towards a sustainability criteria and indicators framework for legacy mine land. Journal of Cleaner Environment, 17(16) 1426-1434.

Zafirovski, M., 2005. Social exchange theory under scrutiny: A positive critique of its economic-behaviourist formulations. Electronic journal of sociology, 2(2) 1-40.

\section{Author Biography}

Estellina Namutebi is an Assistant Lecturer at Uganda Martyrs University in the School of Arts and Social Sciences. She has a Bachelor of Arts in Ethics and Development Studies from the same University and a Master of Arts in Environment Development and Peace with Specialisation in Environmental Governance from the UN-mandated University for Peace in Costa Rica. She has experience and interest in doing environmental research. 